\section{Postoperative Pain after Foraminal Instrumentation with a Reciprocating System and Different Irrigating Solutions}

Emmanuel João Nogueira Leal da Silva ${ }^{1}$, Maria Rachel Monteiro², Felipe Gonçalves Belladonna ${ }^{3}$, José Flávio Almeida ${ }^{2}$, Gustavo De-Deus ${ }^{1}$, Aline de Almeida Neves ${ }^{4}$
'Department of Endodontics, UNIGRANRIO - Universidade Grande Rio, Duque de Caxias, RJ, Brazil ${ }^{2}$ Department of Restorative Dentistry, Endodontic Division, UNICAMP - Universidade Estadual de Campinas, Campinas, SP, Brazil ${ }^{3}$ Department of Endodontics, UFF - Universidade Federal

Fluminense, Niterói, RJ, Brazil ${ }^{4}$ Department of Pediatric Dentistry and Orthodontics, UFRJ Universidade Federal do Rio de Janeiro, Rio de Janeiro, RJ, Brazil

Correspondence: Dr. Emmanuel João Nogueira Leal da Silva, Rua Herotides de Oliveira 61/902, lcaraí, 24230-230 Niterói, RJ, Brasil. Tel: +55-21-2610-8439. e-mail: nogueiraemmanuel@hotmail.com

Key Words: irrigants, Reciproc, foraminal instrumentation, postoperative pain.

\section{Introduction}

One of the primary aims of endodontic therapy is to reduce the microbial population in the root canals of infected teeth. This is usually accomplished by mechanical preparation along with the use of irrigating solutions. Although many substances have been suggested for root canal irrigation, sodium hypochlorite $(\mathrm{NaOCl})$ remains the most widely used, because of its pronounced antimicrobial activity and the ability to dissolve organic matter (1). However, $\mathrm{NaOCl}$ may be cytotoxic to periradicular tissues, particularly at high concentrations (1). A recent retrospective study showed that $42 \%$ diplomates of the American Board of Endodontics reported having at least one $\mathrm{NaOCl}$ accident in their practice career (2). For this reason, postoperative pain is a major concern when highly concentrated $\mathrm{NaOCl}$ solutions are used in nonvital teeth because of the extravasation risk of the irrigant into these tissues.

Chlorhexidine (CHX) has been proposed as a potential substitute for $\mathrm{NaOCl}$ given its optimum antimicrobial action, high substantivity and low toxicity (3-5) which might reduce postoperative pain during endodontic treatment.
The apical limit of root canal instrumentation is another controversial topic in root canal therapy. There is some evidence that cleaning, debridement and enlargement of the apical foramen during root canal instrumentation allow a greater reduction of intracanal bacteria load and less hard tissue debris. This maneuver may overcome the limitations of irrigation in the apical area, optimizing root canal disinfection $(6,7)$. A recent study suggested that foraminal instrumentation should be performed for the sake of endodontic treatment predictability without considerably increasing postoperative pain (8). However, up to now, no clinical study has shown whether different irrigants during foraminal instrumentation procedures provide more favorable results in terms of postoperative pain.

The purpose of the present study was to evaluate and compare the postoperative pain after foraminal instrumentation using $5.25 \% \mathrm{NaOCl}$ or $2 \% \mathrm{CHX}$ gel irrigation protocol in nonvital single rooted teeth. The tested null hypothesis was that there is no difference in postoperative pain reported by the patients using $5.25 \% \mathrm{NaOCl}$ or $2 \% \mathrm{CHX}$ gel as irrigating solution during 
instrumentation procedures.

\section{Material and Methods}

After Ethics Committee approval (protocol number 024/2013), all volunteers invited to participate in this parallel clinical trial were informed of the procedures protocols, risks and benefits, and their right to selfdetermination regarding participation. A written consent was signed and a copy was delivered to all volunteers.

\section{Patient Selection}

Approximately 460 patients attended endodontic practice during recruitment, which lasted one year. Among these patients, 62 were selected to take part in this clinical trial. Inclusion criteria were defined as follows: healthy (ASA I) adults over 18 years of age $(n=62)$ participated in this prospective and randomized clinical trial. None of the patients enrolled in this clinical trial was taking any medication that could alter his/her perception of pain (analgesics or non-steroidal anti-inflammatory drugs NSAIDs). They presented single canal teeth diagnosed with asymptomatic necrosis confirmed by a negative response to heat, cold, percussion and palpation tests, clear radiographic observation of a single canal without any sign of pulp obliteration or calcifications from the pulp chamber to the apex, and evidence of apical periodontitis (8). The heat test was performed using a pre-heated gutta-percha cone placed on the middle third of the buccal surface of the teeth and the cold test was performed with the aid of a cold spray (Endo-Frost; Coltène-Whaledent, Langenau, Germany) placed on a cotton pellet and immediately applied on the middle third of the buccal surface of the candidate tooth. If no response was seen after $10 \mathrm{~s}$, the test result was considered negative.

Exclusion criteria included other diagnoses such as deep periodontal pockets, persistent exudate, or if there was failure to achieve apical patency. Immunosuppressed, immunocompromised or pregnant patients were also excluded.

The patients were randomly assigned to one of the groups by means of a restricted adaptive randomization procedure. In one group, 5.25\% NaOCl (B'Herzog; Rio de Janeiro, RJ, Brazil) was used as the irrigant solution during treatment, while for the other group, 2\% CHX gel (EndoGel; Essencial Pharma, Itapetininga, SP, Brazil) and 0.9\% saline solution were used. CHX gel consisted of a gel base (1\% natrosol) and $\mathrm{CHX}$ at pH 7.0.

\section{Treatment Protocol}

After local infiltration with $3.6 \mathrm{~mL}$ of $2 \%$ lidocaine with 1:100,000 epinephrine anesthetic solution (Alphacaine; DFL Indústria e Comércio Ltda, Rio de Janeiro, RJ, Brazil), a rubber dam was placed, and the access cavity was prepared using sterile carbide burs. If the patient recorded any pain sensation during the procedure, a supplemental local infiltration with $1.8 \mathrm{~mL}$ of $2 \%$ lidocaine with $1: 100,000$ epinephrine was administered.

First, an initial exploration of the root canal was performed with size 10, 15 and $20 \mathrm{~K}$-files (VDW, Munich, Germany), under constant irrigation, to establish the apparent root canal length. Only cases where a $30 \mathrm{~K}$-file did not go passively to the working length were selected. These cases were classified as medium and R40 was recommended, according to the manufacturer's protocol. Then, a R40 Reciproc instrument (VDW) was advanced in the root canal until reaching $2 / 3$ of the radiographic estimated working length (WL), and then, moved in a slow and gentle in-and-out pecking motion with $3 \mathrm{~mm}$ amplitude limit. After three complete pecking movements, the instrument was removed from the canal and its flutes were cleaned by insertion into a spoon-box. At this point, the root canal was irrigated as described below. The WL was confirmed by an electronic apex locator (Novapex; Forum Technologies, Rishon Le-Zion, Israel). For both groups, the WL was established at the " 0.0 " reading of the electronic apex locator. Root canal preparation with R40 instrument was then completed reaching the full $\mathrm{WL}$, using the same kinematics described above.

In the $\mathrm{NaOCl}$ group, each insertion of the $\mathrm{R} 40$ instrument was followed by canal irrigation with $3 \mathrm{~mL}$ of a $5.25 \% \mathrm{NaOCl}$ solution. The smear layer was then removed with $3 \mathrm{~mL}$ of 17\% EDTA for $3 \mathrm{~min}$ and the canals were irrigated again with $3 \mathrm{~mL}$ of $5.25 \% \mathrm{NaOCl}$.

In the CHX group, the root canals were flooded with the $2 \% \mathrm{CHX}$ gel before each insertion of the R40 instrument and afterwards rinsed with $3 \mathrm{~mL}$ of $0.9 \%$ saline solution. The smear layer was then removed with $3 \mathrm{~mL}$ of 17\% EDTA for $3 \mathrm{~min}$, and the canals were irrigated again with $3 \mathrm{~mL}$ of saline solution.

In both groups, the irrigation solutions were kept in and dispensed using a 30-G Max-i-Probe needle (Dentsply Maillefer, Ballaigues, Switzerland) up to $3 \mathrm{~mm}$ short of the $W L$, verified by rubber stops.

All teeth received the same volume of irrigants. After instrumentation, the root canals were dried with absorbent paper points (Denstply Maillefer) and filled with gutta-percha (Odous; Odous De Deus Ltda, Belo Horizonte, MG, Brazil) and AH Plus sealer (Dentsply De Trey, Konstanz, Germany) using warm vertical compaction with the continuous-wave technique (Touch'n Heat; SybronEndo) and gutta-percha backfill. After endodontic treatment, all patients received postoperative instructions for taking analgesics (400 $\mathrm{mg}$ ibuprofen) in case they experienced pain (8). 


\section{Analysis of Postoperative Pain and Statistical Analysis}

Assessment of postoperative pain was conducted for 3 days after the initial session. Pain was recorded as absent, slight, moderate or severe, and scores from 1 to 4 were attributed to each classification of pain (8): no pain (1), the patient feels well; slight pain (2), if the patient is distracted, he/she does not feel the pain and no analgesic is required; moderate pain (3), the patient feels moderate pain even while concentrating on some other activity and analgesic is required; and severe pain (4), the patient is no longer able to perform any type of activity, needs to lie down and seek dentist help (analgesics had little or no effect in relieving the pain). The number of analgesic tablets used was also recorded.

The findings were recorded for statistical evaluation using SPSS software version 19.0 (SPSS Inc, Chicago, IL, USA). Chi-Square test, Kolmogorov-Smirnov and Student's $\mathrm{t}$ tests were used to determine significant differences assuming $\alpha=5 \%$.

\section{Results}

A total of 62 volunteers (23 men and 39 women) were enrolled in this study (Fig. 1). Chi-square test showed the homogeneity between groups in the proportion of male and female patients $(p>0.05)$. The mean age (mean \pm standard deviation) of the patients were $43.9 \pm 12.2$ years in the $\mathrm{NaOCl}$ group and $41.8 \pm 13.5$ years in the $\mathrm{CHX}$ group. No statistically significant differences in age between the 2 groups were found ( $p>0.05$, Student's t test), as seen in Table 1. Regarding postoperative pain, no statistically significant differences were seen between the groups at any observation period ( $p>0.05$, Table 2 ). In addition, no significant difference among the groups was observed in the mean number of used analgesic tablets ( $p>0.05$, Table $3)$. The percentage of subjects reporting no or mild pain after $24 \mathrm{~h}$ for the $\mathrm{NaOCl}$ and $\mathrm{CHX}$ groups was $74.1 \%$ and $80.6 \%$, respectively (Fig. 2). After $48 \mathrm{~h}, 87.1 \%$ of the $\mathrm{NaOCl}$ group and $90.3 \%$ of the $\mathrm{CHX}$ group reported no or mild

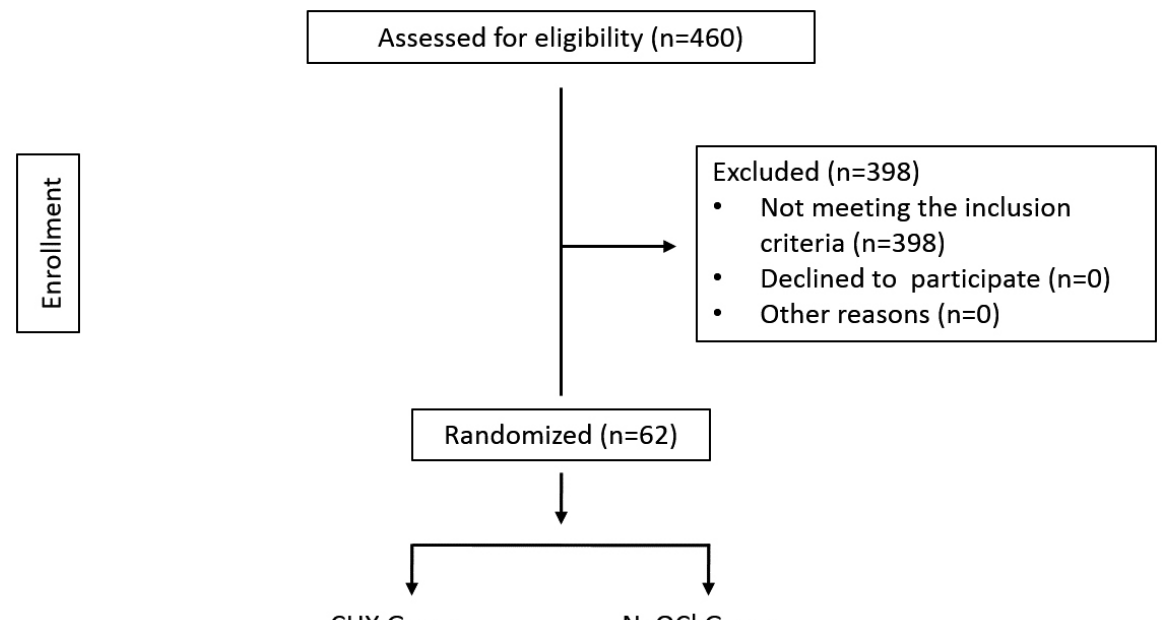

CHX Group

$\mathrm{NaOCl}$ Group

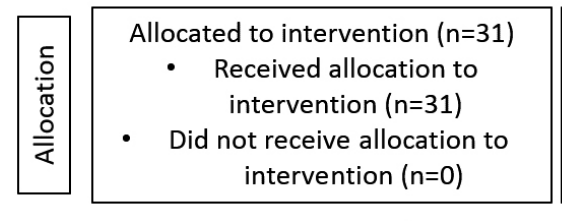

Allocated to intervention $(n=31)$

- Received allocation to intervention $(n=31)$

- Did not receive allocation to intervention $(n=0)$
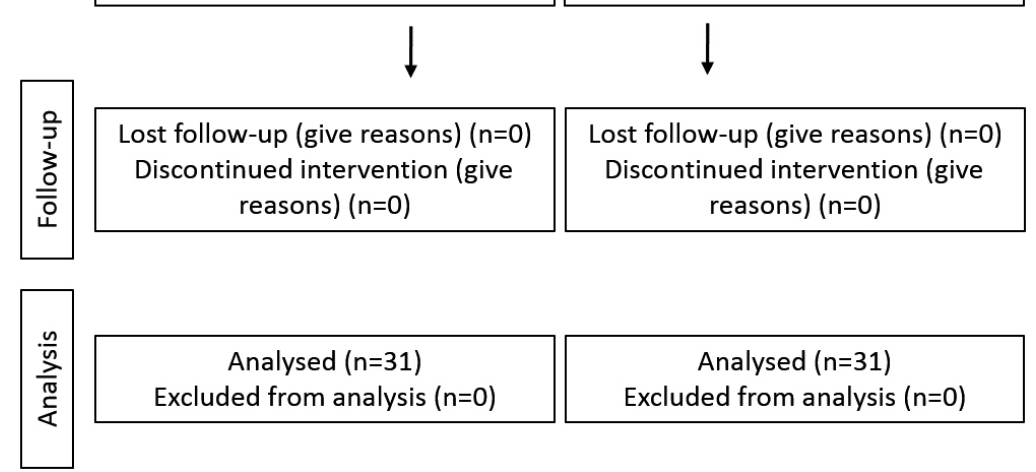
pain. After $72 \mathrm{~h}$, moderate pain was observed in only $3.2 \%$ of the $\mathrm{NaOCl}$ group and $6.4 \%$ of the $\mathrm{CHX}$ group. Only one patient in the $\mathrm{NaOCl}$ group reported severe pain after $24 \mathrm{~h}$.

\section{Discussion}

Discomfort after endodontic treatment is usually ascribed to a tissue response caused by one or more factors, including failure at the cleaning and shaping stages, extrusion of infected debris and damage to the periradicular tissue when foraminal enlargement is performed (9). Overinstrumentation may be a mechanical cause, whereas chemical factors include extrusion of intracanal dressings, filling materials or irrigants (10). Irrigation is a necessary and important step throughout all root canal system preparation, but it may lead to extrusion of irrigating solutions whether manual or rotary instruments are used (11). Therefore, it is logical to assume that the use of a nontoxic and biocompatible substance is required to avoid or diminish postoperative discomfort. The most used auxiliary chemical substances in endodontic therapy are $\mathrm{NaOCl}$ and $\mathrm{CHX}$ at different concentrations.

In the present study, the volunteers were randomized into 2 experimental groups. In one group, foraminal instrumentation was performed using $\mathrm{NaOCl}$ as the irrigant while in the other group a combination of $\mathrm{CHX}$ and saline solution was used during foraminal instrumentation. As no statistically significant difference was observed between the groups $(p<0.05)$, it can be suggested that the irrigating solutions used in the present study had little or no influence on postoperative pain during foraminal instrumentation. Therefore, both solutions can be applied to promote better disinfection during endodontic instrumentation, resulting in more treatment predictability concerning short-term follow up regarding postoperative pain.

Regarding the different irrigating solutions used

Table 1. Demographic features

\begin{tabular}{lcc}
\hline & $\mathrm{NaOCl}(\mathrm{n}=31)$ & $\mathrm{CHX}(\mathrm{n}=31)$ \\
\hline Age (years) & $43.9 \pm 12.2$ & $41.8 \pm 13.5$ \\
Sex & 10 men and 21 women & 13 men and 18 women \\
\hline
\end{tabular}

$p>0.05$ - Student's t test.

Table 2. Mean and standard deviation of pain scores in the $\mathrm{NaOCl}$ and $\mathrm{CHX}$ groups at different time points

\begin{tabular}{lccc}
\hline Group & $24 \mathrm{~h}$ & $48 \mathrm{~h}$ & $72 \mathrm{~h}$ \\
\hline $\mathrm{NaOCl}$ & $1.70 \pm 0.93$ & $1.51 \pm 0.72$ & $1.25 \pm 0.51$ \\
$\mathrm{CHX}$ & $1.58 \pm 0.80$ & $1.41 \pm 0.67$ & $1.25 \pm 0.56$ \\
\hline
\end{tabular}

$p>0.05$ - Student's t test. in the present study, a recent clinical trial showed no significant differences in postoperative pain when endodontic treatment was performed without foraminal instrumentation in patients with chronic apical periodontitis using $5.25 \% \mathrm{NaOCl}$ or 2\% $\mathrm{CHX}$ gel with saline solution (12). In addition, another randomized clinical study comparing $5.25 \% \mathrm{NaOCl}$ and $2 \% \mathrm{CHX}$ showed statistically significant difference in postoperative pain only at the 6-h timepoint, where pain was more intense in the $\mathrm{NaOCl}$ group. No statistically significant difference was observed in any other tested time-point (13). In both studies, however, no foraminal instrumentation was performed. To the best of the authors' knowledge, there was no available data on postoperative pain during foraminal instrumentation comparing different irrigating solutions.

Besides the fact that both irrigants apparently decrease bacterial population, a sterile instrumented root canal is far away from reality. Both $\mathrm{NaOCl}$ and $\mathrm{CHX}$ irrigants are supported by literature to be safely used during root canal treatment $(3-5,12,13)$. However, it is important to notice that these successful outcomes in the literature are no indicators of long-term success, but in fact, only predictors of postoperative procedures. This fact had been recently demonstrated in a systematic review of endodontic irrigants (14). The conclusions of this review showed that there is still insufficient reliable evidence showing the superiority of $\mathrm{NaOCl}$ or $\mathrm{CHX}$. Also, the strength and reliability of the supporting evidence was variable, suggesting that future

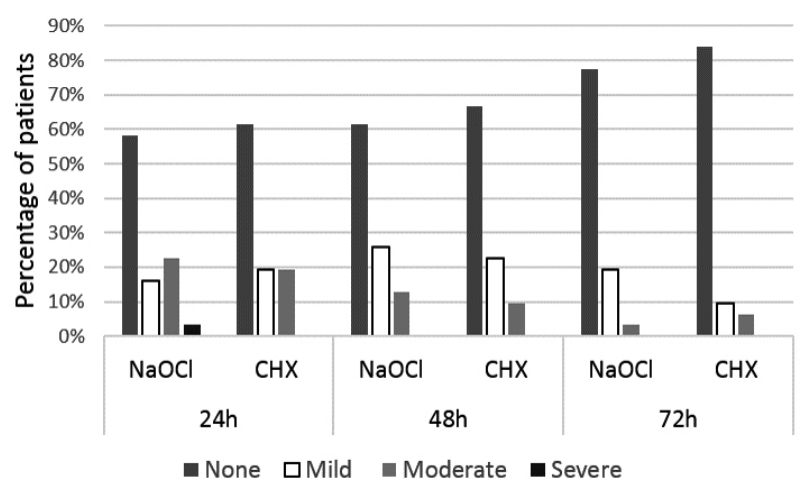

Figure 2. Percentage of subjects in the $\mathrm{NaOCl}$ and $\mathrm{CHX}$ groups with no, mild, moderate and severe postoperative pain at each time point.

Table 3. Mean and standard deviation of number of analgesic tablets used in the $\mathrm{NaOCl}$ and $\mathrm{CHX}$ groups at different time points

\begin{tabular}{lccc}
\hline Group & $24 \mathrm{~h}$ & $48 \mathrm{~h}$ & $72 \mathrm{~h}$ \\
\hline $\mathrm{NaOCl}$ & $0.52 \pm 0.97$ & $0.32 \pm 0.83$ & $0.19 \pm 0.32$ \\
$\mathrm{CHX}$ & $0.47 \pm 0.91$ & $0.35 \pm 0.79$ & $0.14 \pm 0.29$ \\
\hline
\end{tabular}

$p>0.05$ - Student's t test. 
trials should report both clinician-relevant and patientpreferred outcomes at clearly defined preoperative as well as long-term time points.

Reciproc instruments were used in the present study to perform foraminal instrumentation. It is known that the reciprocating movement somehow mimics manual movement (15) and, to some extent, recent studies showed that it outperformed conventional continuous rotary nickel-titanium preparation $(16,17)$. However, some concerns regarding the possibility of higher number of postoperative pain cases have been raised. In two recent studies, single-file reciprocating system was associated with higher postoperative pain when compared to full-sequence rotary $(18,19)$. This higher incidence of postoperative pain could be related to a higher apical extrusion of bacteria, dentin chips, irrigants and inflamed or necrotic pulp tissue, which may elicit postoperative pain. Previous studies concluded that full-sequence rotary instrumentation was related to less debris extrusion than reciprocating singlefile systems $(20,21)$. However, this fact does not represent a consensus in the recent specific literature. In a recent study, reciprocating single-file systems extruded fewer - bacteria apically than a conventional multi-file rotary system (22). Moreover, other studies showed no differences between rotary and reciprocating movements regarding debris extrusion $(23,24)$.

In fact, the low pain rates observed in the present study may be explained by the taken high trans-operatory care. Reciproc instruments were used in a slow in-and-out pecking motion associated to careful canal disinfection and file cleaning after each three movements to prevent dentin chips accumulation. Furthermore, a specific irrigation protocol was performed, reducing even more the possibility of debris accumulation and extrusion using a Max-i-Probe needle, which avoids the positive pressure directly to the apex (25).

In this study, use of $5.25 \% \mathrm{NaOCl}$ or $2 \% \mathrm{CHX}$ gel resulted in similar levels of postoperative pain. Therefore, it may be concluded that both irrigants are acceptable regarding short-term postoperative pain during root canal instrumentation with foraminal instrumentation.

\section{Resumo}

0 objetivo do presente estudo foi avaliar e comparar a dor pós-operatória após a instrumentação foraminal usando $\mathrm{NaOCl} 5,25 \%$ ou gel de $\mathrm{CHX} 2 \%$ em dentes não vitais unirradiculares após instrumentação reciprocante. Sessenta e dois voluntários, apresentando um único canal radicular diagnosticado com necrose assintomática e periodontite apical, foram randomizados em dois grupos experimentais de acordo com o protocolo de irrigação (ou seja, grupos de $\mathrm{NaOCl}$ 5,25\% e CHX gel 2\%). 0 tratamento endodôntico foi realizado em uma única visita sob instrumentação reciprocante com instrumentação foraminal. Os voluntários foram instruidos a registrar a intensidade da dor. Escores de 1-4 foram atribuidos a cada tipo de dor após 24, 48 e $72 \mathrm{~h}$. Testes de Kolmogorov-Smirnov e t de Student foram utilizados para determinar diferenças significativas em $p<0,05$. Em média, o percentual de pacientes que teve nenhumaou leve dor após 24,48 ou $72 \mathrm{~h}$ foi de $77.4 \%, 88.7 \%$ e $95.1 \%$, respectivamente. Não foi encontrada diferença de idade estatisticamente significante entre os grupos ( $p>0,05$, teste $t$ de Student). A dor pós-operatória não apresentou diferença estatisticamente significativa em qualquer periodo de observação ao usar $\mathrm{NaOCl} 5,25 \%$ ou $\mathrm{CHX}$ gel $2 \%$ ( $p>0,05)$. Além disso, não foi observada diferença significativa no número médio de comprimidos analgésicos utilizados entre os grupos $(p>0,05)$. 0 uso de $\mathrm{NaOCl} 5,25 \%$ ou $\mathrm{CHX}$ gel $2 \%$ resultou na mesma dor pós-operatória. Portanto, pode-se inferir que a escolha do irrigante não tem relação com um acompanhamento a curto prazo em relação a dor pós-operatória.

\section{References}

1. Zehnder M. Root canal irrigants. J Endod 2006;32:389-398.

2. Kleier DJ, Averbach RE, Mehdipour 0. The sodium hypochlorite accident: experience of diplomates of the American Board of Endodontics. J Endod 2008;34:1346-1350.

3. Ferraz CC, Gomes BP, Zaia AA, Teixeira FB, Souza-Filho FJ. In vitro assessment of the antimicrobial action and mechanical ability of chlorhexidine gel as an endodontic irrigant. J Endod 2001;27:452-455.

4. Rôcas IN, Siqueira JF Jr. Comparison of the in vivo antimicrobial effectiveness of sodium hypochlorite and chlorhexidine used as root canal irrigants: a molecular microbiology study. J Endod 2011;37:143150.

5. Gomes BP, Vianna ME, Zaia AA, Almeida JF, Souza-Filho FJ, Ferraz CC. Chlorhexidine in endodontics. Braz Dent J 2013;24:89-102.

6. Souza-Filho FJ, Benatti O, Almeida OP. Influence of the enlargement of the apical foramen in periapical repair of contaminated teeth of dog. Oral Surg Oral Med Oral Pathol 1987;64:480-484.

7. Card SJ, Sigurdsson A, Orstavik D, Trope M. The effectiveness of increased apical enlargement in reducing intracanal bacteria. J Endod 2002;28:779-783.

8. Silva EJ, Menaged K, Ajuz N, Monteiro MR, Coutinho-Filho TS. Postoperative pain after foraminal enlargement in anterior teeth with necrosis and apical periodontitis: a prospective and randomized clinical trial. J Endod 2013;39:173-176.

9. $\mathrm{Ng} \mathrm{YL}$, Mann V, Gulabivala K. A prospective study of the factors affecting outcomes of nonsurgical root canal treatment: Part 1: periapical health. Int Endod J 2011;44:583-609.

10. Nair PN, Henry S, Cano V, Vera J. Microbial status of apical root canal system of human mandibular first molars with primary apical periodontitis after "one-visit" endodontic treatment. Oral Surg Oral Med Oral Pathol Oral Radiol Endod 2005;99:231-252.

11. Tambe VH, Nagmode PS, Vishwas JR, P SK, Angadi P, Ali FM. Evaluation of the amount of debris extruded apically by using conventional syringe, Endovac and ultrasonic irrigation technique: an in vitro study. J Int Oral Health 2013;5:63-66.

12. Almeida G, Marques $E$, De Martins AS, da Silveira Bueno CE, Nowakowski A, Cunha RS. Influence of irrigating solution on postoperative pain following single-visit endodontic treatment: randomized clinical trial. J Can Dent Assoc 2012;78:c84.

13. Bashetty $K$, Hedge J. Comparison of $2 \%$ chlorhexidine and $5.25 \%$ sodium hypochlorite irrigating solutions on postoperative pain: a randomized clinical trial. Indian J Dent Res 2010;21:523-527.

14. Fedorowicz Z, Nasser M, Sequeira-Byron P, de Souza RF, Carter B, Heft $\mathrm{M}$. Irrigants or non-surgical root canal treatment in mature permanent teeth. Cochrane Database Syst Rev 2012;9:CD008948.

15. Ruddle CJ. Canal preparation: single-file shaping technique. Dent Today 2012;31:126-129.

16. Marzouk AM, Ghoneim AG. Computed tomographic evaluation of canal shape instrumented by different kinematics rotary nickel-titanium systems. J Endod 2013;39:906-909.

17. Pedullà E, Grande NM, Plotino G, Gambarini G, Rapisarda E. Influence of continuous or reciprocating motion on cyclic fatigue resistance of 4 different nickel-titanium rotary instruments. J Endod 2013;39:258261.

18. Gambarini G, Testarelli L, De Luca M, Milana V, Plotino G, Grande NM, 
et al.. The influence of three different instrumentation techniques on the incidence of postoperative pain after endodontic treatment. Ann Stomatol (Roma) 2013;20:152-155.

19. Gambarini G, Sudani DAL, Di Carlo S, Pompa G, Pacifici A, Pacifici L, et al.. Incidence and intensivity of postoperative pain and periapical inflammation after endodontic treatment with two different instrumentation techniques. Europ J Inflam 2012;10:99-103.

20. Bürklein S, Schäfer E. Apically extruded debris with reciprocating single-file and full-sequence rotary instrumentation systems. J Endod 2012;38:850-852.

21. Bürklein $S$, Benten $S$, Schäfer E. Quantitative evaluation of apically extruded debris with different single-file systems: Reciproc, F360 and OneShape versus Mtwo. Int Endod J 2014;47:405-409.

22. Tinoco JM, De-Deus G, Tinoco EM, Saavedra F, Fidel RA, Sassone LM. Apical extrusion of bacteria when using reciprocating single-file and rotary multifile instrumentation systems. Int Endod J 2014:47:560-566.

23. De-Deus G, Brandão $M C$, Barino $B$, Di Giorgi $K$, Fidel RA, Luna AS Assessment of apically extruded debris produced by the single-file ProTaper F2 technique under reciprocating movement. Oral Surg Oral Med Oral Pathol Oral Radiol Endod 2010;110:390-394.

24. Koçak S, Koçak MM, Sağlam BC, Türker SA, Sağsen B, Er Ö. Apical extrusion of debris using self-adjusting file, reciprocating single-file, and 2 rotary instrumentation systems. J Endod 2013;39:1278-1280.

25. Khan S, Niu LN, Eid AA, Looney SW, Didato A, Roberts S, et al.. Periapical pressures developed by nonbinding irrigation needles at various irrigation delivery rates. J Endod 2013;39:529-533.

Received October 31, 2014

Accepted January 5, 2015 